\title{
Interlaboratory tests of paving grade bitumen and polymer modified bitumen
}

\begin{abstract}
In the paper the results of interlaboratory round-robin tests are presented. The RR program was executed for paving grade 50/70 bitumen and polymer modified bitumen 45/80-55. For both binders similar test programs have been prepared, starting from fundamental properties like Pen@25, Softening Point, Softening Point after RTFOT, Fraass breaking point, elastic recovery etc. and with use of more contemporary test methods as complex modulus $\mathrm{G}^{*}$, phase angle $\delta\left(60^{\circ} \mathrm{C}, \mathrm{f}=1.59 \mathrm{~Hz}(10 \mathrm{rad} / \mathrm{s}), \mathrm{PMB}\right.$ microstructure etc. Finally 8 properties for unmodified bitumen were tested and 9 for PMBs. In the program 24 laboratories from three european countries participated representing different kinds of labs - private owned, technical universities, road administration and refinery control labs. The final results were evaluated with statistical and z-score method. Surprisingly results showed that the best methods with high reproductibility are complex modulus $\mathrm{G}^{*}$ and phase angle $\delta$.
\end{abstract}

Key words: interlaboratory tests, round-robin tests, paving grade bitumen, polymer modified bitumen, statistical evaluation.

\section{Badania porównawcze asfaltów drogowych i modyfikowanych polimerami (PMB)}

W artykule zaprezentowano wyniki badań międzylaboratoryjnych zorganizowanych przez ORLEN Asfalt w 2012 roku. Program badań obejmował dwa rodzaje lepiszczy asfaltowych: asfalt drogowy 50/70 według PN-EN 12591 oraz asfalt modyfikowany polimerami PMB 45/80-55 według PN-EN 14023. Wśród wybranych parametrów oceny asfaltu drogowego 50/70 i modyfikowanego PMB 45/80-55 znalazły się badania obligatoryjne (zawarte w normach, w oparciu o które produkowane są asfalty) oraz badania funkcjonalne oznaczane w reometrze dynamicznego ścinania DSR. Finalnie do porównań wybrano 8 właściwości asfaltu drogowego i 9 właściwości asfaltu modyfikowanego. W badaniach międzylaboratoryjnych wzięły udział 24 laboratoria reprezentujące zarówno inwestorów z branży drogowej jak i typowe jednostki badawcze. Otrzymane wyniki badań zostały poddane analizie statystycznej i ocenione zgodnie z ogólnymi zasadami opisanymi w normach: PN-EN ISO/IEC 17043:2011 Ocena zgodności-Ogólne wymagania dotyczące badania biegłości oraz ISO 13528:2005 Statistical methods for use in proficiency testing by interlaboratory comparisons.

Słowa kluczowe: badania międzylaboratoryjne, badania porównawcze, asfalt drogowy, asfalt modyfikowany, analiza statystyczna.

\section{Introduction}

The ORLEN Asfalt Research and Development Department has been making analyses of bitumens and gathering the data of the tests conducted for many years. The results of our own research, as well as that of other research institutions which we have obtained via data exchange during road construction-related conferences and seminars, have led the authors of this article to conduct an analysis of the deviations in the results of bituminous binders achieved by various laboratories, and by different operators (reproducibility). The scope of the project was an assessment 
of credibility received test results for paving grade and modified bitumen.

In mid-2012, ORLEN Asfalt organised a proficiency test $t^{l}$ via inter-laboratory comparison ${ }^{2}$, on the basis of guide- lines included in standards PN-EN ISO/IEC 17043:2011 and ISO 13528:2005. The statistical processing of the test results was carried out by the ORLEN Laboratorium Sp. z o.o. company of the PKN ORLEN Corporate Group [4, 5, 6].

\section{Purpose, Object and Scope of Performed Tests}

The purpose of the performed test project was an objective and impartial assessment of the quality of parameters of selected paving grade and modified bituminous binders by various road laboratories.

The tests were carried out on paving grade bitumen 50/70 (sample A) as per PN-EN 12591, and polymer modified bitumen PMB 45/80-55 (sample B), as per PN-EN 14023 (National Annexe of 2011). Bitumen samples with a volume of 30 litres were extracted from ready-made products tanks on one of the large-tank installations belonging to ORLEN Asfalt Sp. z o.o., in accordance with PN-EN 58 (pt. 8.1.2. Sampling valve installed in tank walls). Each sample was mixed in order to achieve exact homogeneity. Afterwards 30 "sub-samples" were extracted from the sample, with a volume of 1 litre each. The sub-samples were packaged in cardboard boxes lined internally with aluminium foil - specially designed for transporting and storage of bituminous binders. Such prepared and tagged

Table 1. Scope of compared selected tests of paving grade bitumen 50/70 (Sample A) and polymer modified bitumen PMB 45/80-55 (Sample B)

\begin{tabular}{|c|c|c|c|c|c|}
\hline No. & Property & Abbreviation & $\begin{array}{l}\text { Unit of } \\
\text { Measurement }\end{array}$ & $\begin{array}{c}50 / 70 \\
(\text { Sample A) }\end{array}$ & $\begin{array}{c}45 / 80-55 \\
(\text { Sample B) }\end{array}$ \\
\hline 1. & Penetration at $25^{\circ} \mathrm{C}$ as per PN-EN 1426:2009 & Pen25 1) 2) & $0.1 \mathrm{~mm}$ & Yes & Yes \\
\hline 2. & R\&B softening point, as per PN-EN 1427:2009 & $\mathrm{SP}^{1) 2)}$ & ${ }^{\circ} \mathrm{C}$ & Yes & Yes \\
\hline 3. & Fraass breaking point, as per PN-EN 12593:2009 & Fraass ${ }^{1)}{ }^{2)}$ & ${ }^{\circ} \mathrm{C}$ & Yes & Yes \\
\hline 4. & Elastic recovery at $25^{\circ} \mathrm{C}$ as per PN-EN 13398:2012 & ER25 ${ }^{2)}$ & $\%$ & No & Yes \\
\hline 5. & Paraffin content, distillation method as per PN-EN 12606-1:2009 & Paraf ${ }^{1)}$ & $\% \mathrm{~m} / \mathrm{m}$ & Yes & No \\
\hline 6. & $\begin{array}{l}\text { Complex module } \mathrm{G}^{*} \text { in temperature of } 60^{\circ} \mathrm{C} \text {, frequency } 1.59 \mathrm{~Hz} \\
(10 \mathrm{rad} / \mathrm{s}) \text {, plate-plate arrangement, plate diam. } 25 \mathrm{~mm} \text {, gap } \\
1 \mathrm{~mm} \text {, testing in controlled stress mode, with the stress value set } \\
\text { at } 0.12 \mathrm{kPa}(120 \mathrm{~Pa}) \text { in DSR as per PN-EN } 14770: 2009\end{array}$ & $\mathrm{G}^{*}$ 1)2) & $\mathrm{kPa}$ & Yes & Yes \\
\hline 7. & $\begin{array}{l}\text { Phase angle } \delta \text { in temperature of } 60^{\circ} \mathrm{C} \text {, frequency } 1.59 \mathrm{~Hz} \\
(10 \mathrm{rad} / \mathrm{s}) \text {, plate-plate arrangement, plate diam. } 25 \mathrm{~mm} \text {, gap } \\
1 \mathrm{~mm} \text {, testing in controlled stress mode, with the stress value set } \\
\text { at } 0.12 \mathrm{kPa}(120 \mathrm{~Pa}) \text { in DSR as per PN-EN 14770:2009 }\end{array}$ & Delta $^{1) 2)}$ & $\circ$ & Yes & Yes \\
\hline 8. & $\begin{array}{l}\text { Softening point R\&B after RTFOT hardening as per PN-EN } \\
\text { 1427:2009 and PN-EN 12607-1:2009 }\end{array}$ & $\mathrm{SP}^{\mathrm{RTFOT} 1 \text { 1) 2) }}$ & ${ }^{\circ} \mathrm{C}$ & Yes & Yes \\
\hline 9. & $\begin{array}{l}\text { Increase of softening point R\&B after RTFOT hardening as per } \\
\text { PN-EN 1427:2009 and PN-EN 12607-1:2009 }\end{array}$ & $\Delta \mathrm{SP}^{\mathrm{RTFOT}}$ 1) 2) & ${ }^{\circ} \mathrm{C}$ & Yes & Yes \\
\hline 10. & $\begin{array}{l}\text { Force ductility. Energy value at } 5^{\circ} \mathrm{C} \text { as per PN-EN 13589:2011 } \\
\text { and PN-EN 13703:2009 }\end{array}$ & FD5 $^{2)}$ & $\mathrm{J} / \mathrm{cm}^{2}$ & No & Yes \\
\hline 11. & $\begin{array}{l}\text { Visual assessment of dispergation of polymer in polymer modi- } \\
\text { fied bitumen (sample B) as per PN-EN 13632:2010 }\end{array}$ & Image & - & No & Yes \\
\hline
\end{tabular}

${ }^{1)}$ Abbreviation of full description of tested characteristic used in Table 2 and 3.

${ }^{2)}$ Abbreviation of full description of tested characteristic used in Table 4 and 5 .

${ }^{1}$ (PT - Proficiency Testing) - determination, via inter-laboratory comparisons, of the ability of a laboratory to perform tests or ratings (sometimes proficiency testing is also called EQA - External Quality Assurance) [1].

${ }^{2}$ (ILC - Interlaboratory Comparisons) - organisation, performance and evaluation of tests or ratings of the same or various objects of testing or rating by at least two different laboratories, in accordance with previously defined conditions [1]. testing materials "Sample A" and "Sample B" were simultaneously handed over to the comparative test participants via a logistics company.

The selected parameters for the assessment of paving grade bitumen 50/70 and polymer modified bitumen PMB 45/80-55 included obligatory tests (admitted in EN standards serving as the basis for bitumen production) and additional functional 
tests in a Dynamic Shear Rheometer (DSR). The functional tests (currently excluded from the scope of product specification standards) are much better in terms of quality characterisation of bituminous binders than strictly standard tests, which should be considered rather as type-classification tests or commercial quality-defining tests. The scope of the compared selected tests of paving grade bitumen and polymer modified bitumen is shown in Table 1 .

\section{Information about Test Project Participants and Confidentiality of obtained results}

24 laboratories participated in the interlaboratory comparison tests, which included facilities representing road construction investors, as well as standard research institutions. The structure of institutions administrating the participating laboratories was as follows:

- State-owned belonging to the national road administration in Poland -8 ,

- Technical universities and research institutes -7,

- Road construction companies - 5,

- Private - 1,

- Bitumen manufacturers -3 .

Among the 24 laboratories, 8 had certificates of accreditation accordant with standard EN ISO 17025. It has to be noted that the scope of accreditation of the laboratories did not fully cover the tests conducted under the proficiency test programme [1].

In view of generally accepted regulations governing comparison tests, the organizer of the tests - ORLEN Asfalt guaranteed the confidentiality of all information related to the participation in the programme of all participants. Therefore, for the purposes of the project, all names of laboratories have been coded by appropriating to them randomly chosen numbers from 1 to 24, and each participant has been given its own personal code number. Each participant was also obliged to carry out the tests and hand over the results directly and only to the organizer, without contacting any of the other laboratories.

\section{Implemented Methodology of Statistical Evaluation of Results}

Test results received from the Participants of interlaboratory tests were subject to standard statistical evaluation, using a MS Excel spreadsheet. The list of obtained results and calculated statistical measures are shown in Table 2 and 3 (for paving grade bitumen 50/70) and in Table 4 and 5 (for polymer modified bitumen PMB 45/80-55). One exception is the evaluation of the results of visual assessment of dispergation of polymer in polymer modified bitumen (PMB), where in accordance with the appropriate standard, the obtained result does not represent a number, but a microscopic image and the implemented code of description of the microstructure. In this case, statistical approach to the evaluation of obtained results, as was done in the case of other test results, is not possible, and the evaluation of variation in test results can only be done in a descriptive way.

In accordance with the implemented methodology of statistical evaluation of test results, the definition of attributed value $X^{*}$, standard uncertainty of attributed value $u_{x}$, standard deviation for the evaluation of proficiency $\sigma^{\wedge}$ and the evaluation of the tests results obtained by the participants, was carried out in accordance with the general rules described in standards [3] and [2], with the consideration of the following particular boundary conditions implemented for the purposes of this analysis:

- Attributed value $X^{*}$ was defined as the mean value of laboratory test results received from the participants, with the consideration of techniques minimising the effect of extreme values using the resistant statistical method of Algorithm A [2]. The attributed value is the so-called "resistant mean value" $[4,6]$.

- The standard uncertainty $u_{x}$ of the attributed value $X^{*}$ was estimated only for the purpose of tests, where the number of participating laboratories was less than $10[4,6]$.

- The estimated standard uncertainty was compared to standard deviation applied to the evaluation of proficiency $s^{\wedge}$. If the criterion of $u_{x} \leq 0,3 s^{\wedge}$ was not fulfilled, the effect of the uncertainty of definition of the attributed value on the evaluation of results of tests obtained by the participants was taken into account, i.e. instead of $z$-score, the value of $z$ '-score was applied $[4,6]$.

- For the purpose of evaluation of test results, resistant standard deviation $s^{*}$, estimated on the basis of results sent by the participants, was applied instead of the standard deviation for evaluation of proficiency $s^{\wedge}$. For the purpose of estimation of standard deviation on the basis of test results $s^{*}$, the strong statistical method of Algorithm A was applied $[2,4,6]$.

- Only in one case (analysis of the results of elastic recovery at $25^{\circ} \mathrm{C}$ as per PN-EN 13398:2012) standard deviation calculated on the basis of results sent by the participants $s$ was applied, after the rejection of the extreme value $[4,6]$.

- For the purpose of statistical evaluation of individual results of tests from each of the laboratories, the index of $z$-score, calculated as per formula (1), or $z$ '-score, 
calculated as per formula (2), was applied. The $z$ '-score index was applied in cases when the boundary condition of $u_{x} \leq 0,3 \sigma^{\wedge}$ was not fulfilled $[4,6]$.

$$
\begin{gathered}
z=\frac{x-X^{*}}{\sigma^{\wedge}} \\
z^{\prime}=\frac{x-X^{*}}{\sqrt{\sigma^{\wedge}+u_{x}^{2}}}
\end{gathered}
$$

where:

$x$ - result obtained by the Participant, $X^{*}$ - attributed value, $\sigma^{\wedge}$ - standard deviation, $u_{x}-$ standard uncertainty of attributed value $\mathrm{X}^{*}$.

Test results obtained by the laboratories were subject to evaluation with the implementation of the following criteria in accordance with the $z$-score or $z$ '-score index $[4,6]$ : $|z| \leq 2$ - satisfactory result, $2<|z|<3$ - questionable result, $|z| \geq 3$ - unsatisfactory result.

For the purposes of complementing the statistical evaluation carried out according to the $z$-score or $z$ 'score index, the test results were further expanded with standard statistical measures for data sets, i.e. arithmetic average, median ${ }^{3}$, standard deviation ${ }^{4}$, minimum value, maximum value and range ${ }^{5}$.

\section{Obtained Interlaboratory Test Results and their Statistical Evaluation}

\begin{tabular}{|c|c|c|c|c|c|c|c|c|}
\hline \multirow{3}{*}{ Method } & \multicolumn{2}{|c|}{ Pen25 } & \multicolumn{2}{|c|}{ SP } & \multicolumn{2}{|c|}{ Fraass } & \multicolumn{2}{|c|}{ Paraf } \\
\hline & result & evaluation & result & evaluation & result & evaluation & result & evaluation \\
\hline & {$[0.1 \mathrm{~mm}]$} & $z$-score & {$\left[{ }^{\circ} \mathrm{C}\right]$} & $z$-score & {$\left[{ }^{\circ} \mathrm{C}\right]$} & $z$ 'score & {$[\% \mathrm{~m} / \mathrm{m}]$} & $z$-score \\
\hline No. of test participants $p$ & \multicolumn{2}{|c|}{24} & \multicolumn{2}{|c|}{23} & \multicolumn{2}{|c|}{13} & \multicolumn{2}{|c|}{7} \\
\hline Attributed Value $X^{*}$ & & 61.750 & & 49.100 & & -16.130 & & 1.650 \\
\hline Std. Dev. $s^{*}$ & & 3.147 & & 0.556 & & 3.474 & & 0.575 \\
\hline Uncertainty of Attr. Val. $u_{x}$ & & 0.800 & & 0.100 & & 1.200 & & - \\
\hline Arithm. Ave. & 61.20 & & 49.10 & & -16.20 & & 1.70 & \\
\hline Median & 62.00 & & 49.00 & & -17.00 & & 1.70 & \\
\hline Std. Dev. & 4.77 & & 0.50 & & 3.16 & & 0.51 & \\
\hline Min. Value & 48.20 & & 48.30 & & -22.00 & & 0.87 & \\
\hline Max. Value & 72.00 & & 50.00 & & -12.00 & & 2.30 & \\
\hline Range & 23.80 & & 1.70 & & 10.00 & & 1.43 & \\
\hline $\begin{array}{l}\text { Comments to Statistical } \\
\text { Evaluation of Results }\end{array}$ & $\begin{array}{l}24 \text { laboratorie } \\
\text { the compariso } \\
\text { evaluated on } t \\
\text { z-score. } \\
\text { Nineteen labo } \\
\text { ved satisfacto } \\
\text { laboratories a } \\
\text { nable results, } \\
\text { tories achieve } \\
\text { ry results. }\end{array}$ & $\begin{array}{l}\text { articipated in } \\
\text { Results were } \\
\text { basis of } \\
\text { tories achie- } \\
\text { results, three } \\
\text { ieved questio- } \\
\text { d two labora- } \\
\text { unsatisfacto- }\end{array}$ & $\begin{array}{l}23 \text { laborato } \\
\text { pated in the } \\
\text { Results we } \\
\text { on the basi } \\
\text { Laboratori } \\
\text { tisfactory } r\end{array}$ & $\begin{array}{l}\text { es partici- } \\
\text { comparison. } \\
\text { evaluated } \\
\text { f } z \text {-score. } \\
\text { achieved sa- } \\
\text { ults. }\end{array}$ & $\begin{array}{l}13 \text { laborato } \\
\text { pated in the } \\
\text { Results wer } \\
\text { on the basis } \\
\text { because sta } \\
\text { tainty of th } \\
\text { value was g } \\
0.3 s^{\wedge} \text {. } \\
\text { Laboratorie } \\
\text { tisfactory re }\end{array}$ & $\begin{array}{l}\text { es partici- } \\
\text { omparison. } \\
\text { evaluated } \\
\text { of } z \text {-score, } \\
\text { dard uncer- } \\
\text { attributed } \\
\text { eater than } \\
\text { achieved sa- } \\
\text { ults. }\end{array}$ & $\begin{array}{l}7 \text { laboratories } \\
\text { the comparisol } \\
\text { evaluated on tl } \\
z \text {-score. } \\
\text { Laboratories a } \\
\text { factory results } \\
\text { Due to a smal } \\
\text { ticipating labo } \\
\text { above assessm } \\
\text { an informative }\end{array}$ & $\begin{array}{l}\text { ticipated in } \\
\text { Results were } \\
\text { pasis of } \\
\text { ieved satis- } \\
\text { umber of par- } \\
\text { ories, the } \\
\text { thas } \\
\text { le only. }\end{array}$ \\
\hline
\end{tabular}

Table 2. Comparative test results and their statistical evaluation - Sample A - paving grade bitumen 50/70

Tables 2, 3 and 4, 5 [4, 6] present results of comparative tests received from 24 laboratories participating in the research programme, including their statistical analysis and basic statistical measures. Table 6 [5] presents the results of comparative tests of the visual assessment of dispergation of polymer. Due to the specific character of these results, their analysis is limited to a descriptive comment.

\footnotetext{
${ }^{3}$ The value of a characteristic located in an ordered series, with identical number of observations above and below it.

${ }^{4}$ Informs how far the values in a given set are scattered beyond its arithmetic average. The smaller value of standard deviation, the bigger the concentration of observed values around the arithmetic average.

${ }^{5}$ The difference between the lowest and highest value of a statistical characteristic in a given set.
} 
Table 3. Comparative test results and their statistical evaluation - Sample A - paving grade bitumen 50/70 (continued)

\begin{tabular}{|c|c|c|c|c|c|c|c|c|}
\hline \multirow{3}{*}{ Method } & \multicolumn{2}{|c|}{$\mathrm{G}^{*}$} & \multicolumn{2}{|c|}{ Delta } & \multicolumn{2}{|c|}{$\mathrm{SP}^{\mathrm{RTFOT}}$} & \multicolumn{2}{|c|}{$\Delta \mathrm{SP}^{\mathrm{RTFOT}}$} \\
\hline & result & evaluation & result & evaluation & result & evaluation & result & evaluation \\
\hline & {$[\mathrm{kPa}]$} & z-score & {$\left[{ }^{\circ}\right]$} & $z$-score & {$\left[{ }^{\circ} \mathrm{C}\right]$} & $z$ 'score & {$\left[{ }^{\circ} \mathrm{C}\right]$} & $z$-score \\
\hline No. of test participants $p$ & \multicolumn{2}{|c|}{7} & \multicolumn{2}{|c|}{7} & \multicolumn{2}{|c|}{14} & \multicolumn{2}{|c|}{14} \\
\hline Attributed Value $X^{*}$ & & 2.540 & & 84.710 & & 54.330 & & 5.130 \\
\hline Std. Dev. $s^{*}$ & & 0.064 & & 0.311 & & 0.525 & & 0.512 \\
\hline Uncertainty of Attr. Val. $u_{x}$ & & - & & - & & 0.200 & & - \\
\hline Arithm. Ave. & 2.50 & & 84.70 & & 54.30 & & 5.10 & \\
\hline Median & 2.50 & & 84.70 & & 54.40 & & 5.20 & \\
\hline Std. Dev. & 0.06 & & 0.35 & & 0.59 & & 0.47 & \\
\hline Min. Value & 2.45 & & 84.00 & & 52.80 & & 4.40 & \\
\hline Max. Value & 2.60 & & 85.10 & & 55.00 & & 6.00 & \\
\hline Range & 0.16 & & 1.07 & & 2.20 & & 1.60 & \\
\hline $\begin{array}{l}\text { Comments to Statistical } \\
\text { Evaluation of Results }\end{array}$ & $\begin{array}{l}7 \text { laborator } \\
\text { in the com } \\
\text { were evalu } \\
\text { of } z \text {-score. } \\
\text { Laboratori } \\
\text { satisfactor } \\
\text { Due to a s1 } \\
\text { participati } \\
\text { the above } \\
\text { an informa }\end{array}$ & $\begin{array}{l}\text { participated } \\
\text { son. Results } \\
\text { on the basis } \\
\text { chieved } \\
\text { sults. } \\
\text { number of } \\
\text { aboratories, } \\
\text { ssment has } \\
\text { role only. }\end{array}$ & $\begin{array}{l}7 \text { laboratori } \\
\text { the compar } \\
\text { evaluated o } \\
z \text {-score. } \\
\text { Six laborat } \\
\text { factory rest } \\
\text { achieved a } \\
\text { Due to a sn } \\
\text { participatin } \\
\text { above asses } \\
\text { mative role }\end{array}$ & $\begin{array}{l}\text { rticipated in } \\
\text { Results were } \\
\text { basis of } \\
\text { achieved satis- } \\
\text { ne laboratory } \\
\text { ionable result. } \\
\text { umber of } \\
\text { oratories, the } \\
\text { thas an infor- }\end{array}$ & $\begin{array}{l}14 \text { laborat } \\
\text { pated in th } \\
\text { Results } \mathrm{w} \\
\text { the basis c } \\
\text { cause stan } \\
\text { of the attri } \\
\text { greater th } \\
\text { Thirteen 1 } \\
\text { achieved } \\
\text { results, on } \\
\text { achieved } \\
\text { result. }\end{array}$ & $\begin{array}{l}\text { es partici- } \\
\text { omparison. } \\
\text { evaluated on } \\
\text {-score, be- } \\
\text { d uncertainty } \\
\text { ed value was } \\
3 s^{\wedge} \text {. } \\
\text { ratories } \\
\text { sfactory } \\
\text { boratory } \\
\text { estionable }\end{array}$ & $\begin{array}{l}14 \text { laborat } \\
\text { pated in th } \\
\text { Results w } \\
\text { the basis o } \\
\text { Laborator } \\
\text { satisfactor }\end{array}$ & $\begin{array}{l}\text { s partici- } \\
\text { omparison. } \\
\text { evaluated on } \\
\text { score. } \\
\text { achieved } \\
\text { esults. }\end{array}$ \\
\hline
\end{tabular}

Table 4. Comparative test results and their statistical evaluation - Sample B - polymer modified bitumen PMB 45/80-55

\begin{tabular}{|c|c|c|c|c|c|c|c|c|}
\hline \multirow{3}{*}{ Method } & \multicolumn{2}{|c|}{ Pen25 } & \multicolumn{2}{|c|}{ SP } & \multicolumn{2}{|c|}{ Fraass } & \multicolumn{2}{|c|}{ ER25 } \\
\hline & result & evaluation & result & evaluation & result & evaluation & result & evaluation \\
\hline & {$[0.1 \mathrm{~mm}]$} & z-score & {$\left[{ }^{\circ} \mathrm{C}\right]$} & z-score & {$\left[{ }^{\circ} \mathrm{C}\right]$} & $z$-score & {$[\%]$} & z-score \\
\hline No. of test participants $p$ & \multicolumn{2}{|c|}{23} & \multicolumn{2}{|c|}{22} & \multicolumn{2}{|c|}{13} & \multicolumn{2}{|c|}{18} \\
\hline Attributed Value $X^{*}$ & & 56.710 & & 62.20 & & -19.130 & & 84.430 \\
\hline Std. Dev. $s^{*}$ & & 2.706 & & 1.118 & & 3.967 & & 1.392 \\
\hline Uncertainty of Attr. Val. $u_{x}$ & & 0.700 & & 0.3 & & 1.400 & & 0.400 \\
\hline Arithm. Ave. & 56.80 & & 62.20 & & -19.10 & & 84.40 & \\
\hline Median & 56.00 & & 62.20 & & -19.00 & & 84.80 & \\
\hline Std. Dev. & 5.41 & & 1.06 & & 3.50 & & 1.94 & \\
\hline Min. Value & 41.00 & & 60.50 & & -25.00 & & 82.00 & \\
\hline Max. Value & 73.80 & & 64.60 & & -13.70 & & 90.00 & \\
\hline Range & 32.80 & & 4.10 & & 11.30 & & 8.00 & \\
\hline $\begin{array}{l}\text { Comments to Statistical } \\
\text { Evaluation of Results }\end{array}$ & $\begin{array}{l}23 \text { laborator } \\
\text { in the comp } \\
\text { were evalua } \\
\text { of } z \text {-score. } \\
\text { Twenty one } \\
\text { achieved sat } \\
\text { two laborato } \\
\text { unsatisfactor }\end{array}$ & $\begin{array}{l}\text { participated } \\
\text { son. Results } \\
\text { on the basis } \\
\text { oratories } \\
\text { actory results, } \\
\text { s achieved } \\
\text { results. }\end{array}$ & $\begin{array}{l}22 \text { laborator } \\
\text { the compari } \\
\text { evaluated on } \\
z \text {-score. } \\
\text { Twenty one } \\
\text { achieved sat } \\
\text { one laborato } \\
\text { a questionab }\end{array}$ & $\begin{array}{l}\text { articipated in } \\
\text { Results were } \\
\text { basis of } \\
\text { ratories } \\
\text { ctory results, } \\
\text { chieved } \\
\text { esult. }\end{array}$ & $\begin{array}{l}13 \text { laborato } \\
\text { pated in the } \\
\text { Results we } \\
\text { the basis of } \\
\text { cause stand } \\
\text { of the attrib } \\
\text { greater thar } \\
\text { Laboratorie } \\
\text { satisfactory }\end{array}$ & $\begin{array}{l}\text { s partici- } \\
\text { omparison. } \\
\text { evaluated on } \\
\text {-score, be- } \\
\text { d uncertainty } \\
\text { ed value was } \\
.3 s^{\wedge} \text {. } \\
\text { achieved } \\
\text { sults. }\end{array}$ & $\begin{array}{l}18 \text { laborat } \\
\text { pated in th } \\
\text { Results w } \\
\text { the basis } \\
\\
\text { Seventeen } \\
\text { achieved } \\
\text { results, on } \\
\text { achieved } \\
\text { result. }\end{array}$ & $\begin{array}{l}\text { s partici- } \\
\text { omparison. } \\
\text { evaluated on } \\
\text { score. } \\
\text { oratories } \\
\text { factory } \\
\text { boratory } \\
\text { nsatisfactory }\end{array}$ \\
\hline
\end{tabular}


Table 5. Comparative test results and their statistical evaluation - Sample B - polymer modified bitumen PMB 45/80-55 (continued)

\begin{tabular}{|c|c|c|c|c|c|c|c|c|c|c|}
\hline \multirow{3}{*}{ Method } & \multicolumn{2}{|c|}{$\mathrm{G}^{*}$} & \multicolumn{2}{|c|}{ Delta } & \multicolumn{2}{|c|}{$\mathrm{SP}^{\mathrm{RTFOT}}$} & \multicolumn{2}{|c|}{$\Delta \mathrm{SP}^{\mathrm{RTFOT}}$} & \multicolumn{2}{|c|}{ FD5 } \\
\hline & result & evaluation & result & evaluation & result & evaluation & result & evaluation & result & evaluation \\
\hline & {$[\mathrm{kPa}]$} & z-score & {$\left[{ }^{\circ}\right]$} & $z$-score & {$\left[{ }^{\circ} \mathrm{C}\right]$} & $z^{\prime}$-score & {$\left[{ }^{\circ} \mathrm{C}\right]$} & $z$ 'score & {$\left[\mathrm{J} / \mathrm{cm}^{2}\right]$} & z-score \\
\hline $\begin{array}{l}\text { No. of test } \\
\text { participants } p\end{array}$ & \multicolumn{2}{|r|}{7} & \multicolumn{2}{|r|}{7} & \multicolumn{2}{|c|}{14} & \multicolumn{2}{|c|}{14} & \multicolumn{2}{|r|}{8} \\
\hline Attributed Value $X^{*}$ & & 4.780 & & 66.010 & & 65.810 & & 3.670 & & 8.110 \\
\hline Std. Dev. $s^{*}$ & & 0.281 & & 0.311 & & 0.586 & & 1.148 & & 1.107 \\
\hline $\begin{array}{l}\text { Uncertainty of } \\
\text { Attr. Val. } u_{x}\end{array}$ & & - & & - & & 0.200 & & - & & - \\
\hline Arithm. Ave. & 4.70 & & 66.00 & & 65.70 & & 3.70 & & 8.00 & \\
\hline Median & 4.80 & & 66.00 & & 65.70 & & 3.60 & & 7.80 & \\
\hline Std. Dev. & 0.23 & & 0.29 & & 0.76 & & 1.11 & & 0.99 & \\
\hline Min. Value & 4.43 & & 65.60 & & 63.80 & & 2.00 & & 6.90 & \\
\hline Max. Value & 5.10 & & 66.40 & & 66.60 & & 5.90 & & 9.80 & \\
\hline Range & 0.67 & & 0.80 & & 2.80 & & 3.90 & & 2.90 & \\
\hline $\begin{array}{l}\text { Comments to Stati- } \\
\text { stical Evaluation of } \\
\text { Results }\end{array}$ & \multicolumn{2}{|c|}{$\begin{array}{l}7 \text { laboratories partici- } \\
\text { pated in the compari- } \\
\text { son. Results were } \\
\text { evaluated on the basis } \\
\text { of } z \text {-score. } \\
\text { Laboratories achieved } \\
\text { satisfactory results. } \\
\begin{array}{l}\text { Due to a small number } \\
\text { of participating } \\
\text { laboratories, the above } \\
\text { assessment has an } \\
\text { informative role only. }\end{array}\end{array}$} & \multicolumn{2}{|c|}{$\begin{array}{l}7 \text { laboratories partici- } \\
\text { pated in the compari- } \\
\text { son. Results were } \\
\text { evaluated on the basis } \\
\text { of } z \text {-score. } \\
\text { Laboratories achieved } \\
\text { satisfactory results. } \\
\text { Due to a small number } \\
\text { of participating } \\
\text { laboratories, the above } \\
\text { assessment has an } \\
\text { informative role only. }\end{array}$} & \multicolumn{2}{|c|}{\begin{tabular}{|l|}
14 laboratories \\
participated in the com- \\
parison. Results were \\
evaluated on the basis \\
of $z^{\prime}$-score, because \\
standard uncertainty of \\
the attributed value was \\
greater than $0.3 \mathrm{~s}^{\wedge}$. \\
\\
Twelve laboratories \\
achieved satisfactory \\
results, one laboratory \\
achieved a questionable \\
result, one laboratory \\
achieved an unsatisfac- \\
tory result.
\end{tabular}} & \multicolumn{2}{|c|}{$\begin{array}{l}14 \text { laboratories } \\
\text { participated in the com- } \\
\text { parison. Results were } \\
\text { evaluated on the basis } \\
\text { of } z^{\prime} \text {-score, because } \\
\text { standard uncertainty of } \\
\text { the attributed value was } \\
\text { greater than } 0.3 s^{\wedge} \text {. } \\
\text { Laboratories achieved } \\
\text { satisfactory results. }\end{array}$} & \multicolumn{2}{|c|}{$\begin{array}{l}10 \text { laboratories partici- } \\
\text { pated in the compari- } \\
\text { son. } \\
\text { Two laboratories were } \\
\text { not evaluated, because } \\
\text { they stated „rupture” } \\
\text { in the result column. } \\
\text { Results from eight } \\
\text { laboratories were } \\
\text { evaluated according to } \\
\text { z-score. Laboratories } \\
\text { achieved satisfactory } \\
\text { results. One laboratory } \\
\text { gave results for } \\
\text { a temperature of } 10^{\circ} \mathrm{C} \\
\text { only thus the result } \\
\text { was not evaluated. }\end{array}$} \\
\hline
\end{tabular}

For tests results received from the participants, and for each tested characteristic (apart from the visual assessment of dispergation of polymer in polymer modified bitumen), a statistical analysis of the results was performed on the basis of relevant literature [2] and [3].

All results received from the participants were additionally verified using the Dixon test. In order to detect whether the highest or lowest result value is an outlying value, using the available ordered ascending data set $x i$ for $i=1,2, \ldots, p$, the respective $Q_{\text {max }}$ and $Q_{\text {min }}$ parameters were calculated, and subsequently compared with the Dixon test critical parameter. If the calculated $Q_{\max }$ and $Q_{\min }$ values were higher than the critical value of the Dixon test, then the suspected result was the outlying value. Information concerning the detection of outlying values had a strictly informative character, because the programme used a statistical technique limiting the effect of extreme results using the resistant statistical method Algorithm A [6].

For the purpose of evaluation of test results obtained by the participating laboratories, the $z$-score index was used in the case of 12 parameters. In the case of the definition of the Fraass Breaking Point and the Softening Point R\&B after RTFOT hardening, the results were evaluated according to $z^{\prime}$-score, due to the fact that standard uncertainty of the value attributed to these parameters was greater than $0.3 s^{*}[6]$.

The values of $z$-score and $z$ 'score were determined using the resistant standard deviation $s^{*}$ estimated on the basis of results sent by participants. In the case of determination of elastic recovery at $25^{\circ} \mathrm{C}$, the spread between the results from different participants was very small (seven laboratories achieved identical results of $85 \%$ ), and the estimated value of resistant standard deviation $s^{*}$ was twice lower 
than the value standard deviation of reproducibility of the PN-EN 13398:2012 method. In view of the above, standard deviation $s$ was applied for the purpose of evaluation of this parameter, and calculated on the basis of results sent by participants, following the rejection of outlying value detected via the Dixon test [6].

Table 6. Comparative test results of visual evaluation of dispergation of polymer Sample B - polymer modified bitumen PMB 45/80-55

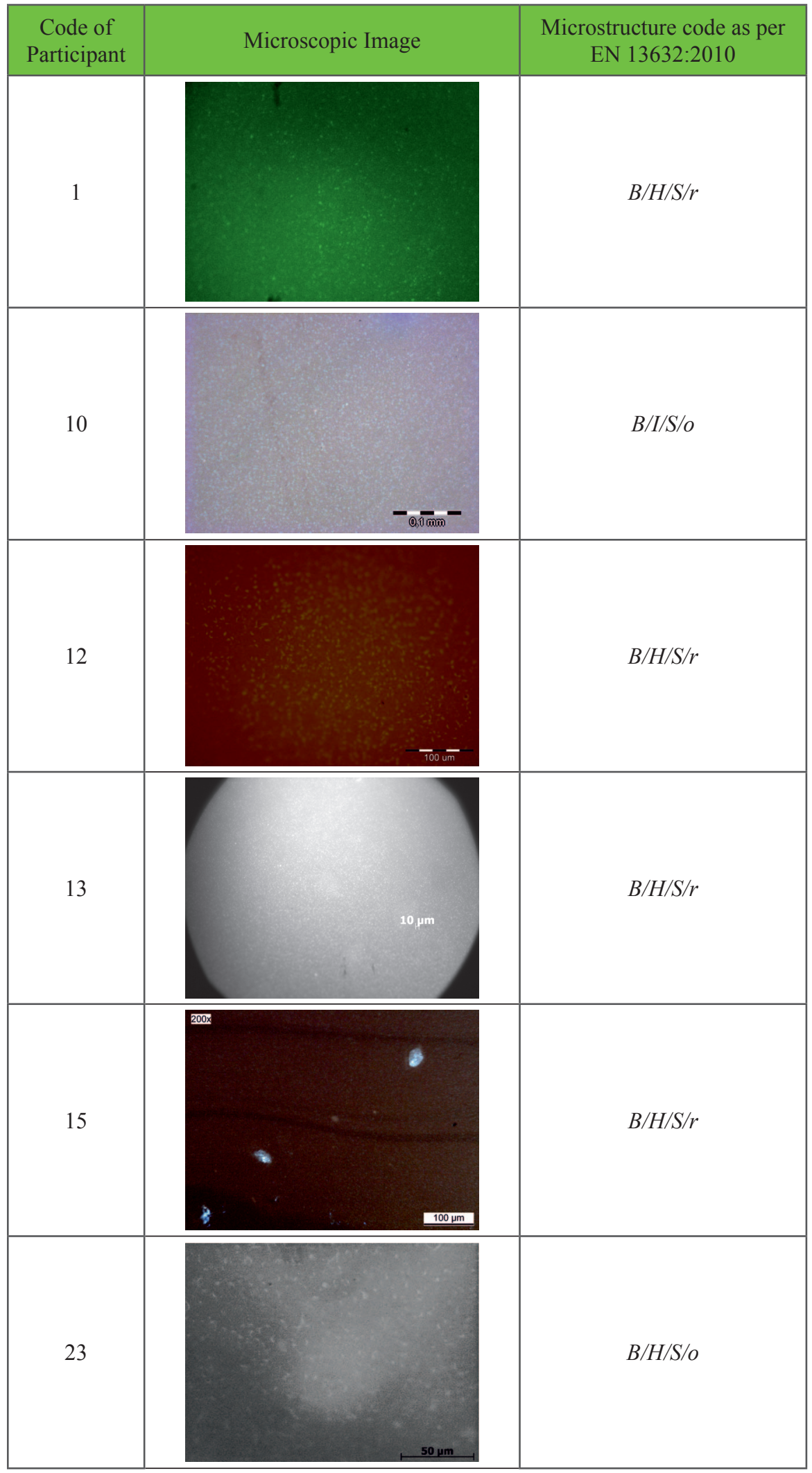




\section{Summary and Conclusions}

The project Testing of Proficiency through Interlaboratory Comparisons organised by ORLEN Asfalt included the participation of 24 laboratories with major experience and certification in the scope of tests which were undertaken in this project.

The project covered standard and non-standard tests of the properties of bituminous binders - paving grade bitumen 50/70 and polymer modified bitumen PMB 45/80-55. Bitumens designated for testing were extracted from manufacturing installations belonging to ORLEN Asfalt.

Paving grade bitumen (sample A) was subject to comparative tests in terms of 8 parameters, while polymer modified bitumen (sample B) was subject to comparison of 9 parameters.

The results of the described project have shown that the weakest results were achieved for the parameter of penetration at $25^{\circ} \mathrm{C}$ (as many as 5 cases of questionable or unsatisfactory results), especially for paving grade bitumen. On the other hand, the most striking results were achieved for Fraass Breaking Point, where for paving grade bitumen, results were obtained in the range of -12 to $-22^{\circ} \mathrm{C}$, and for polymer modified bitumen between -13.7 and $-25^{\circ} \mathrm{C}$. In view of the fact that in most countries, breaking point represents a control test on road construction projects, this may be a cause for concern.

Attention should also be paid to the results of the complex modulus of stiffness $\mathrm{G}^{*}$ and the phase angle $\delta$ for $50 / 70$ bitumen and PMB 45/80-55. In view of relatively short experience with DSR tests and differences in testing equipment used, these results can be considered as very good.

Please cite as: Nafta-Gaz 2016, nr 6, s. 356-363, DOI: 10.18668/NG.2016.05.07

Article contributed to the Editor 4.01.2016. Approved for publication 29.03.2016.

\section{Literature}

[1] Internet webpage of the Polish Accreditation Centre; www.pca. gov.pl (access on: 26.08.2014).

[2] ISO 13528:2005 Statistical methods for use in proficiency testing by interlaboratory comparisons.

[3] PN-EN ISO/IEC 17043:2011 Evaluation of conformity - General requirements regarding proficiency testing.

[4] Proficiency testing by interlaboratory comparisons complementation to report in Lepiszcza asfaltowe No. OA/2012, results of force ductility tests. Energy value at $5^{\circ} \mathrm{C}$ as per PN-EN 13589:2011 and PN-EN 13703:2009. Płock 17.01.2013.

[5] Proficiency testing by interlaboratory comparisons complementation to report in Lepiszcza asfaltowe No. OA/2012, visual assessment of polymer dispergation in polymer-modified bitumen (sample B) as per PN-EN 13632:2010. Płock 17.01.2013.

[6] Proficiency testing by interlaboratory comparisons. Report „Lepiszcza asfaltowe No. OA/2012”, Płock 27.11.2012.

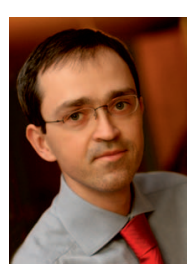

Dr. Krzysztof BŁAŻEJOWSKI, PhD. Eng.

Director. Research and Development

Department of Research and Development

ORLEN Asphalt LLC

39 Łukasiewicz St.

09-400 Płock

E-mail: Krzysztof.Blazejowski@orlen.pl

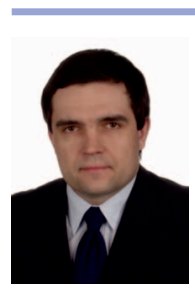

Hubert PECIAKOWSKI M.Sc.

Specialist

Refinery Optimization and Petrochemical Produc-

tion Processes Team

In the field of Refinery Production

PKN ORLEN SC

7 Chemików St., 09-411 Płock

E-mail: Hubert.Peciakowski@orlen.pl

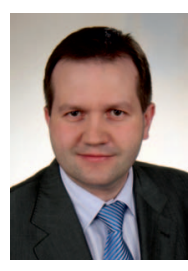

Dr. Jacek OLSZACKI, PhD. Eng.

Specialist

Research and Development of New Technologies

Team in PKN ORLEN

Department of Research and Development of New

Technologies in the ORLEN Capital Group

PKN ORLEN SC

7 Chemików St., 09-411 Płock

E-mail: Jacek.Olszacki@orlen.pl

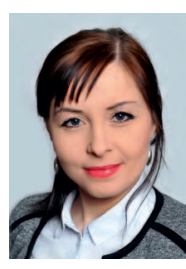

Marta WÓJCIK-WIŚNIEWSKA, M.Sc.Eng

Specialist. Research and Development

Department of Research and Development

ORLEN Asphalt LLC

39 Łukasiewicz St.

09-400 Płock

E-mail: Marta.Wojcik-Wisniewska@orlen.pl 